https://doi.org.10.31743/abmk.2019.112.31

ARTUR HAMRYSZCZAK*- LUBLIN

\title{
OGÓLNOPOLSKA KONFERENCJA NAUKOWA ARCHIWA KOŚCIELNE W NIEPODLEGLEJ POLSCE. LÓDŹ, 14-16 PAŹDZIERNIKA 2019 ROKU
}

W ramach obchodów 100-lecia odzyskania niepodległości przez Polskę, odbyła się w Łodzi konferencja naukowa, zorganizowana przez Naczelną Dyrekcję Archiwów Państwowych we współpracy z Radą Konferencji Episkopatu Polski ds. Kultury i Ochrony Dziedzictwa Kulturowego, Ośrodkiem Archiwów, Bibliotek i Muzeów Kościelnych KUL, Stowarzyszeniem Archiwistów Kościelnych i Archiwum Państwowym w Łodzi. Konferencja uświetniała również 100. rocznicę utworzenia sieci archiwów państwowych w niepodległej Polsce. Objęta została Patronatem Narodowym Prezydenta Rzeczypospolitej Polskiej Andrzeja Dudy w Stulecie Odzyskania Niepodległości, Patronatem Honorowym Wiceprezesa Rady Ministrów, Ministra Kultury i Dziedzictwa Narodowego prof. dr. hab. Piotra Glińskiego oraz Patronatem Honorowym Przewodniczącego Konferencji Episkopatu Polski abpa Stanisława Gądeckiego, metropolity poznańskiego.

Obrady podzielone zostały na sześć bloków tematycznych. Otwarcia sesji dokonał dr Paweł Pietrzyk, Naczelny Dyrektor Archiwów Państwowych wraz bp. warszawskim dr Michałem Janochą, przewodniczącym Rady ds. Kultury i Ochrony Dziedzictwa Kulturowego. W konferencji uczestniczyli również inni przedstawiciele episkopatu: abp dr hab. Grzegorz Ryś, metropolita łódzki i członek Rady ds. Kultury i Ochrony Dziedzictwa Kulturowego oraz bp prof. Jan Kopiec, ordynariusz gliwicki i delegat episkopatu ds. Stowarzyszenia Archiwistów Kościelnych. Do uczestników spotkania skierował swój list wojewoda łódzki Tobiasz Adam Bocheński.

Pierwszy blok tematyczny zatytułowano: Archiwa po odzyskaniu niepodległości. Otworzył go ks. dr hab. Jerzy Adamczyk, prof. UKSW, który przedstawił referat Znaczenie dekretu z dnia 7 lutego 1919 r. o organizacji archiwów państwowych

\footnotetext{
* Artur Hamryszczak - dr historii; asystent naukowy w Ośrodku Archiwów, Bibliotek i Muzeów Kościelnych KUL; e-mail: artur.hamryszczak@kul.pl

https://orcid.org/0000-0002-2578-9971
} 
i opieki nad archiwaliami oraz Kodeksu prawa kanonicznego z 1917 r. dla archiwów kościelnych w II Rzeczypospolitej. W swoim wystąpieniu szczegółowo opisał i zinterpretował normatywy proweniencji państwowej i kościelnej dotyczące przechowywania archiwaliów i instytucji aktotwórczych.

W kolejnym wystąpieniu dr Artur Hamryszczak ukazał jak wspomniane przepisy dotyczące organizacji archiwów były realizowane przez instytucje kościelne (Tworzenie archiwów kościelnych po odzyskaniu przez Polskę niepodległości oraz gromadzenie przez nie zasobu). Jak wspomniał prelegent, w okresie II Rzeczpospolitej tylko w co trzeciej diecezji zorganizowano nowoczesne archiwum historyczne.

Ks. dr Jarosław Wąsowicz przedstawił problem braku fachowych kadr przygotowanych do pracy w archiwach kościelnych (Próby ksztatcenia archiwistów kościelnych $w$ okresie międzywojennym). Prelegent opisał próby podejmowane przez Kościół katolicki i świeckie środowisko naukowe w celu zmiany tego stanu poprzez m.in. kursy archiwalne, staże itp.

Ostatnim prelegentem tej części był abp dr hab. Grzegorz Ryś, który przedstawił referat Ze skarbów archiwalnych prehistorii łódzkiego Kościoła. W swoim wystąpieniu skupił się na przedstawieniu jednego z najcenniejszych dokumentów papieskich przechowywanych w Archiwum Archidiecezji Łódzkiej - list zamknięty (litterae clausae), wystawiony w 1527 r., skierowany do Jana Łaskiego, bratanka prymasa Polski Jana Łaskiego.

Drugi blok tematyczny został zatytułowany Zbiory archiwalne w Polsce 100 lat po odzyskaniu niepodległości. Tę cześć otworzył prof. Paweł Skibiński, który przedstawił Archiwum Prymasa Polski, jego zawartość źródłową i postępy w opracowywania zasobu (Archiwum Sekretariatu Prymasa Polski z czasów prymasów kard. Stefana Wyszyńskiego i Józefa Glempa). Wskazał również na najbardziej typowe problemy z jakimi borykają się archiwiści przy porządkowaniu tej dokumentacji oraz najciekawsze obiekty np. albumy habitów zakonów żeńskich i męskich w okresie reform posoborowych.

Kolejny referat Jak powstawato archiwum zakonne s. dr Marianny (Laurencji) Jędrzejczak, w zastępstwie nieobecnej autorki odczytała s. Bernadeta Żabierek ZSNM. Sięgając do początków powstania Zgromadzenia Sióstr Wspólnej Pracy od Niepokalanej Maryi, założonego w 1910 r. przez bpa Wojciecha Owczarka, przedstawiony został charakter dokumentacji aktowej przechowywanej w archiwum generalnym we Włocławku, stan jego opracowania i udostępnianie kwerendzistom. Ponieważ s. M.L. Jędrzejczak długie lata pracowała z ks. prof. Stanisławem Librowskim w redakcji czasopisma „Archiwa, Biblioteki i Muzea Kościelne” i pod jego kierunkiem przygotowała rozprawę doktorską, nie brakło informacji dotyczących pomocy Ośrodka ABMK w porządkowaniu spuścizny dokumentacyjnej Zgromadzenia.

Ostatni referat Archiwum Kościoła Ewangelicko-Augsburskiego w RP - charakterystyka, przedstawiła Agnieszka Godfrejów-Tarnogórska wskazując na dzieje zasobu i rodzaje przechowywanego zasobu dokumentacyjnego.

Trzeci blok tematyczny został poświęcony kościelnym instytucjom archiwalnym poza granicami Polski (Archiwa kościelne za granica). Pierwszy referat Wspótpraca Naczelnej Dyrekcji Archiwów Państwowych z archiwami polonijny- 
$m i$ wygłosiła Katarzyna Kiliszek. W swoim wystąpieniu skupiła się na prezentacji archiwów polonijnych, którym udzieliła wsparcia merytorycznego i finansowego Naczelna Dyrekcja Archiwów Państwowych. Były to zarówno archiwa kościelne (Polskich Misji Katolickich, zakonne), jak i organizacji polonijnych.

Historię i narastający zasób archiwalny Polskiej Misji Katolickiej w Sztokholmie przedstawił jej długoletni duszpasterz ks. dr hab. Mariusz Chamarczuk (Archiwum Polskiej Misji Katolickiej w Sztokholmie). Zwrócił on uwagę na podstawowe problemy dotyczące narastającej w takich placówkach dokumentacji. Ważnym problemem jest zrozumienie przez duszpasterzy i wiernych wartości źródłowej dokumentów wytworzonych i przechowywanych w budynku misji katolickiej.

W podobnym tonie utrzymane było wystąpienie Jadwigi Kowalskiej, która na podstawie swoich doświadczeń zawodowego archiwisty w Polskiej Misji Katolickiej na Wyspach Brytyjskich, przedstawiła historię, zasób i najważniejsze zadania stojące przed tego typu instytucjami (Archiwum Polskiej Misji Katolickiej w Anglii $i$ Walii).

Ostatni referat w tej części wygłosił ks. dr Wojciech Mleczko CR, który opisał archiwum generalne Zmartwychwstańców w Rzymie (Zasób Archiwum Księży Zmartwychwstańców w Rzymie). Instytucja ta posiada bogaty zasób, m.in. rękopisy Norwida, Krasińskiego, Mickiewicza itp. Dzięki współpracy z NDAP zasób jest konserwowany i digitalizowany.

Czwarty blok tematyczny zatytułowano Zagadnienia i problemy metodyczne. Zainaugurowała go dr hab. Halina Dudała, która poświęciła swoje wystąpienie problemowi archiwum zakonnego (Archiwum zakonne in statu nascendi). $\mathrm{Na}$ podstawie doświadczeń, opisała zasób dokumentacyjny oraz organizację przykładowego klasztoru żeńskiego na terenie Śląska.

Kolejny prelegent, o. dr Ireneusz Wysokiński OP przedstawił archiwum dominikańskie w Krakowie, którego jest dyrektorem (Dzieje Archiwum Polskiej Prowincji Dominikanów a obecna jego struktura). W swoim wystąpieniu opisał historię archiwum na tle dziejów polskich dominikanów, którzy przybyli do Krakowa w 1222 r. I. Wysokiński przedstawił również zasób archiwum oraz prowadzone współcześnie prace inwentaryzacyjne.

Br. Grzegorz Filipiuk OFMCap kierujący archiwum kapucynów w Zakroczymiu, przedstawił placówkę, jej dzieje i zasób (Ukryte i ocalone. Zbiory Archiwum Kapucynów Prowincji Warszawskiej w dziejach Zakonu w Polsce). W swoim wystąpieniu skupił się na prezentacji najcenniejszych obiektów (rękopisy bł. Honorata Koźmińskiego). Wspomniał również o współpracy archiwalnej pomiędzy kapucynami z różnych krajów, którzy cyklicznie spotykają się na sesjach w Rzymie.

Ostatni referat w tej części wygłosił ks. dr hab. Mieczysław Różański, prof. UWM który przedstawił prace zespołu kościelno-państwowego przygotowującego przewodnik metodyczny dla archiwistów pracujących w instytucjach kościelnych (Projekt katalogu dobrych praktyk - opracowywanie i udostepnianie archiwaliów w archiwach kościelnych).

Piąty blok tematyczny zatytułowano: Zagadnienia prawne i finansowe. Rozpoczął go dr Henryk Niestrój, który przedstawił najnowsze normatywy prawne 
dotyczące udostępniania dokumentacji aktowej (Prawne aspekty udostępniania oryginatów i kopii materiałów archiwalnych).

Kolejny referat Wspieranie dziatań archiwalnych - konkursy dotacyjne $\mathrm{Na}$ czelnego Dyrektora Archiwów Państwowych wygtosit dr Bartosz Nowożycki. Omówił on założenia programowe corocznego konkursu NDAP, skierowanego dla archiwów przechowujących niepaństwowy zasób archiwalny. Na podstawie dotychczasowych rozstrzygnięć, ukazał pola działalności archiwalnej, które najczęściej uzyskują wspomnianą dotację.

Jednym z beneficjentów tego programu było archiwum jezuitów w Kłodzku. Henryka Szczepanowska i Mieczysław Kowalcze, przedstawili referat Archiwa jezuitów kłodzkich. Uratować, zabezpieczyć, udostępnić społecznie, czyli UZUS (praktyka w Kłodzku). W swojej prezentacji ukazali etapy redakcji wniosku oraz prace porządkowe i konserwatorskie we wspominanym archiwum.

Referat zamykający blok wygłosił Wojciech Kowaluk, który omówił zniszczenia budynków sakralnych w Łodzi w wyniku działań wojennych (Straty poniesione przez tódzkie światynie $w$ okresie I wojny światowej w świetle źródet przechowywanych $w$ Archiwum Państwowym $w$ Lodzi).

Ostatni blok tematyczny to Popularyzacja zasobu archiwalnego. W pierwszym referacie Czy akta stanu cywilnego w zasobie Archiwum Państwowego $w$ Lodzi kryja dodatkowe treści? Agnieszka Janik przedstawiła wyniki swoich badań. Podczas wnikliwych studiów zapisów metrykalnych odnalazła wiele dopisków przynoszących nowe informacje dotyczące notowanych osób oraz wydarzeń społeczno-politycznych.

Ks. dr hab. Waldemar W. Żurek SDB, prof. KUL opisał cele i działalność powstałego w 1956 r. Ośrodka Archiwów, Bibliotek i Muzeów Kościelnych KUL (Zadania i działania Ośrodka Archiwów, Bibliotek i Muzeów Kościelnych na $K U L)$.

Kolejny referat Działalność Stowarzyszenia Archiwistów Kościelnych oraz indywidualne inicjatywy, był autorstwa prezesa SAK ks. dr hab. Robert Kufla. W swoim wystąpieniu przedstawił historię powołanego w 2004 r. Stowarzyszenia oraz rożne formy jego aktywności (szkolenia, konferencje, wydawanie rocznika „Archiva Ecclesiastica”).

Ostatnie wystąpienie na sesji zaprezentowali: dr Anna Laszuk oraz ks. dr Michał Sołomieniuk omawiając program UNESCO „Pamięć Świata” oraz obiekty kościelne, które się w nim znalazły (Program UNESCO Pamięć Świata-dokumenty $z$ archiwów kościelnych na Liście Swiatowej $i$ Liście Krajowej). Prelegenci analizując wpisane obiekty zauważyli, że jest w nim bardzo mało artefaktów które są własnością Kościoła.

Poszczególne bloki tematyczne wieńczyły dyskusje nad przedstawionymi zagadnieniami w referatach. Uczestnicy konferencji zwiedzili również Archiwum Państwowe w Łodzi, Archiwum Archidiecezjalne i Muzeum Archidiecezji Łódzkiej w Łodzi. Planowane jest wydanie publikacji pokonferencyjnej wzbogaconej o teksty autorów, którzy nie mogli wziąć udziału w sesji.

Słowa kluczowe: archiwa kościelne; archiwa państwowe; zasób archiwalny; Ośrodek ABMK; odzyskanie niepodległości

Keywords: church archives; state archives; archive group; the Institute of Church Libraries, Museums and Archives; regaining independence 


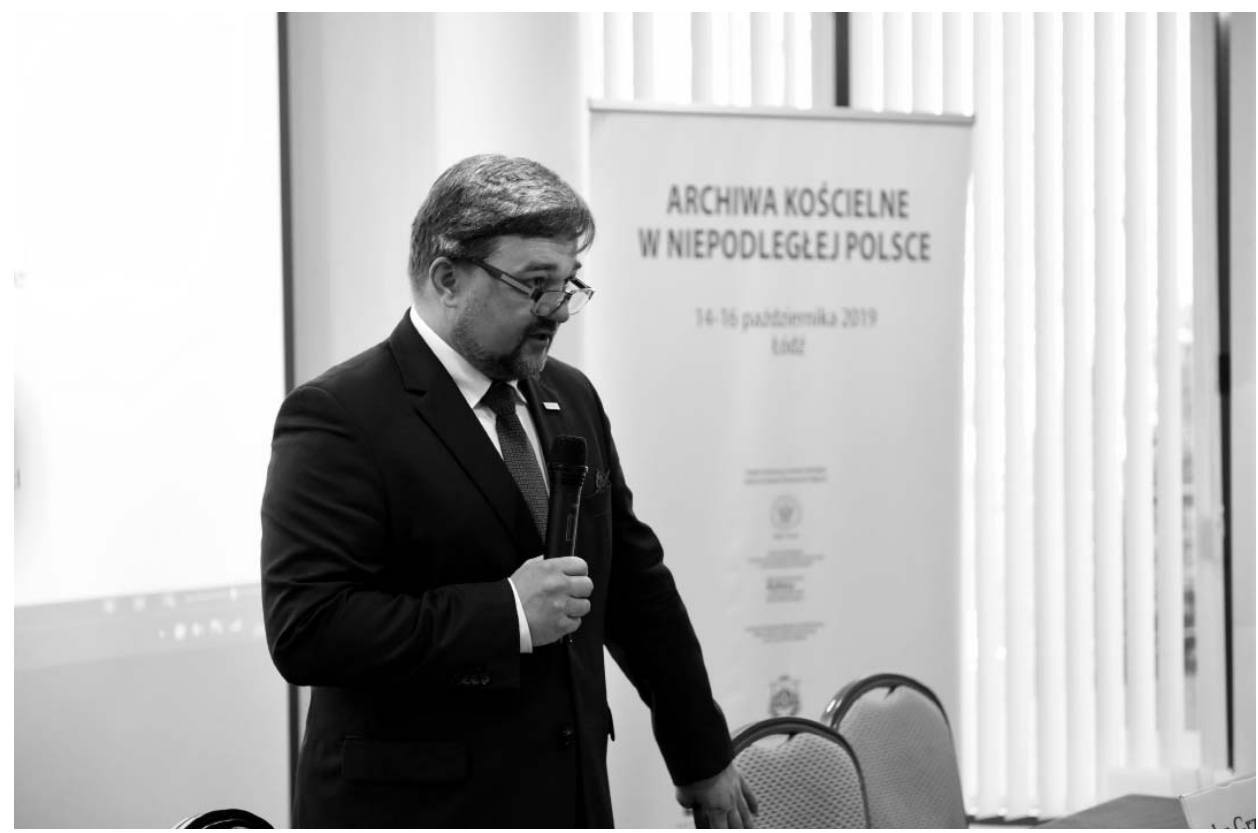

Fot. 1. Otwarcie konferencji Archiwa kościelne w niepodległej Polsce przez Naczelnego Dyrektora Archiwów Państwowych dr. Pawła Pietrzyka. Fot. Jacek Rajkowski.

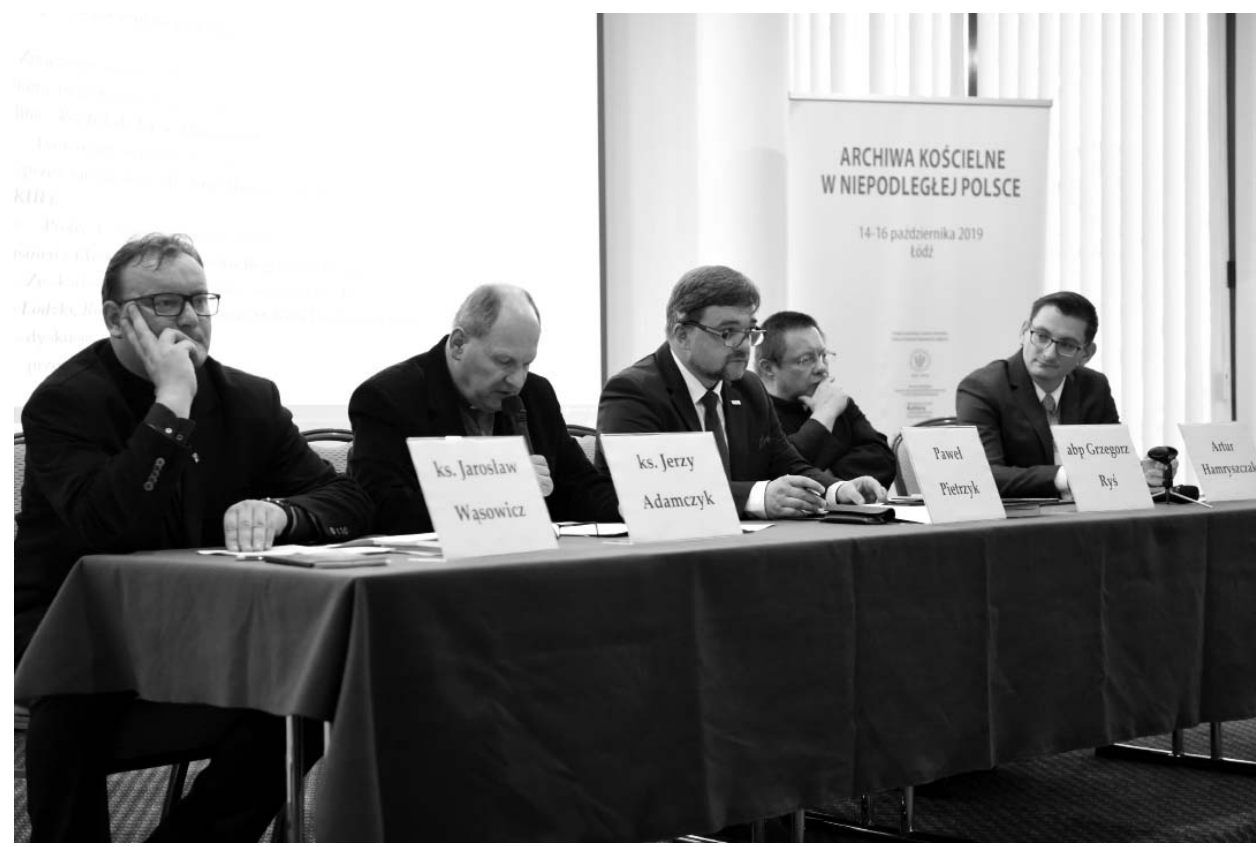

Fot. 2. Wykłady inauguracyjne konferencji Archiwa kościelne w niepodległej Polsce. Fot. Jacek Rajkowski. 


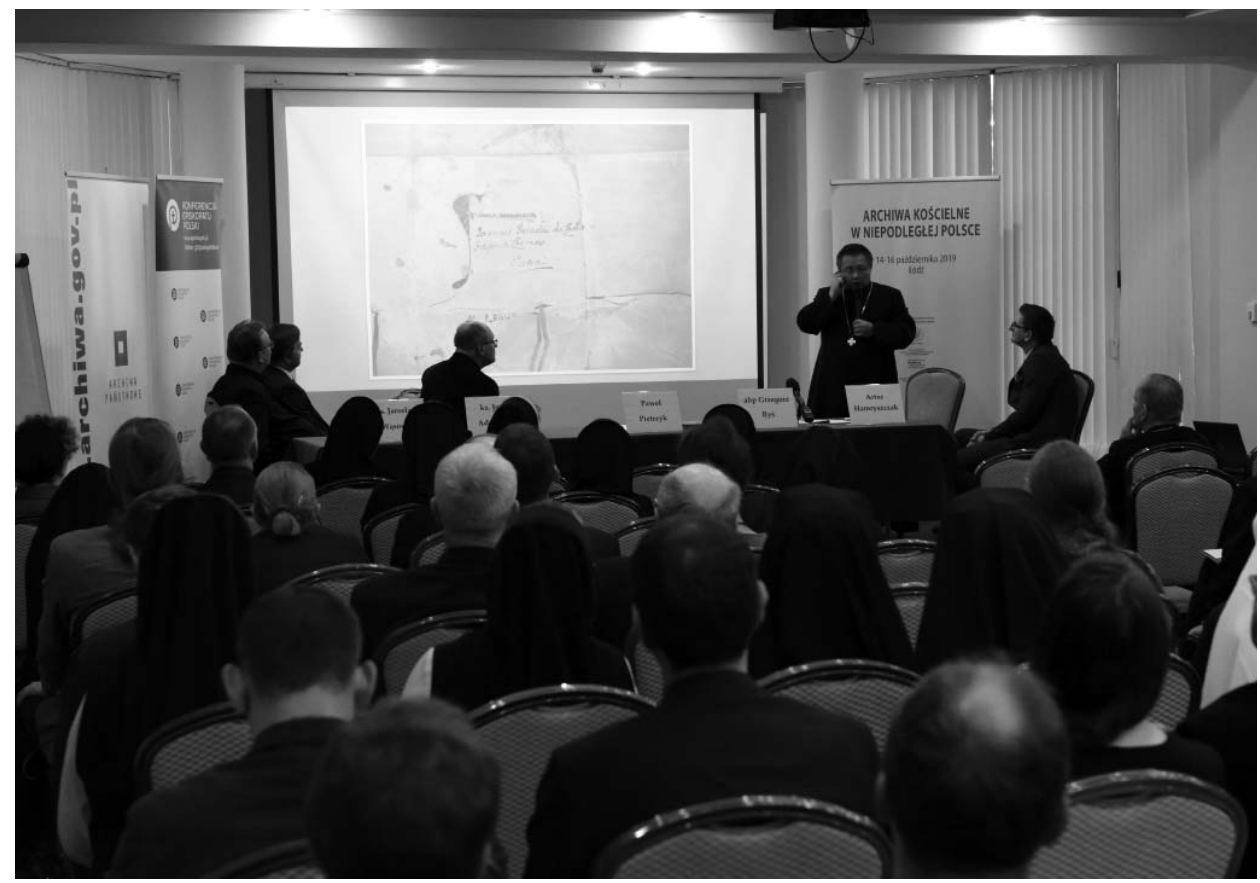

Fot. 3. Wykład abpa dr hab. Grzegorza Rysia Ze skarbów archiwalnych prehistorii łódzkiego Kościoła. Fot. Jacek Rajkowski.

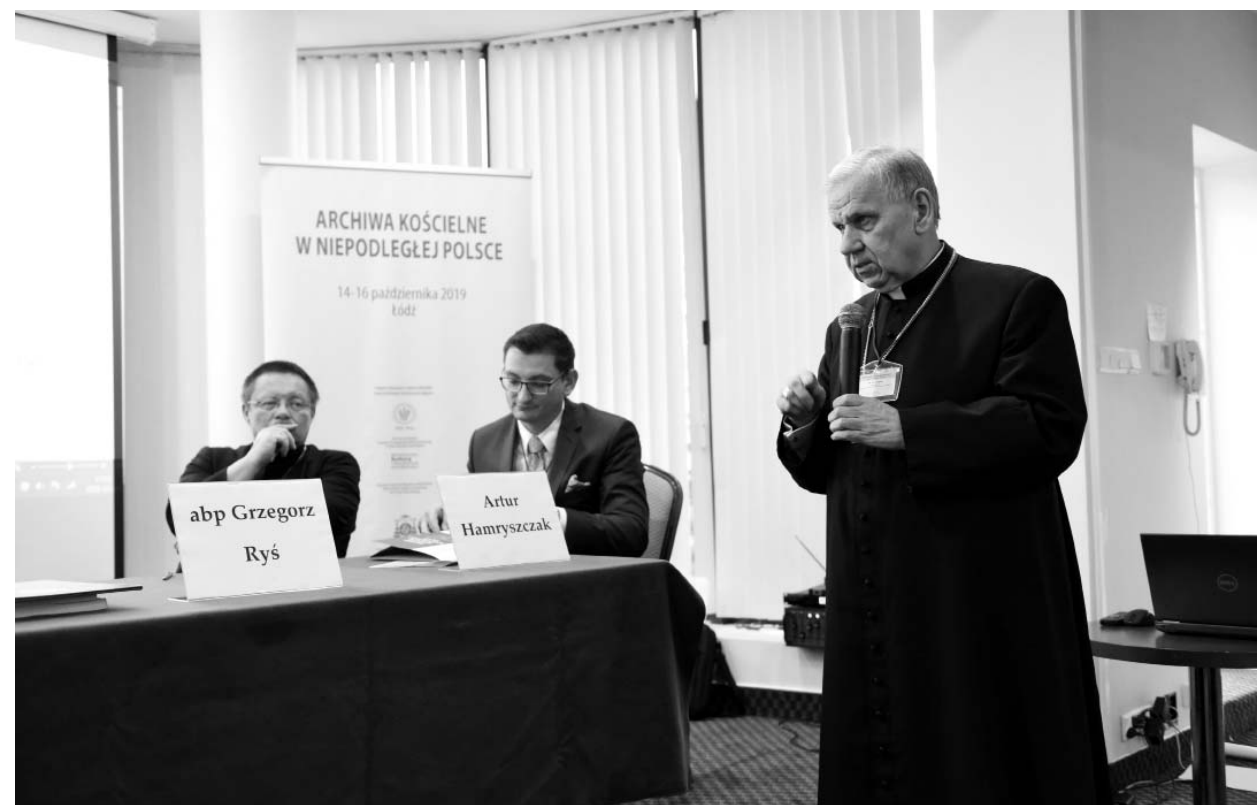

Fot. 4. Wystąpienie bpa prof. Jana Kopca, delegata episkopatu ds. Stowarzyszenia Archiwistów Kościelnych. Fot. Jacek Rajkowski. 


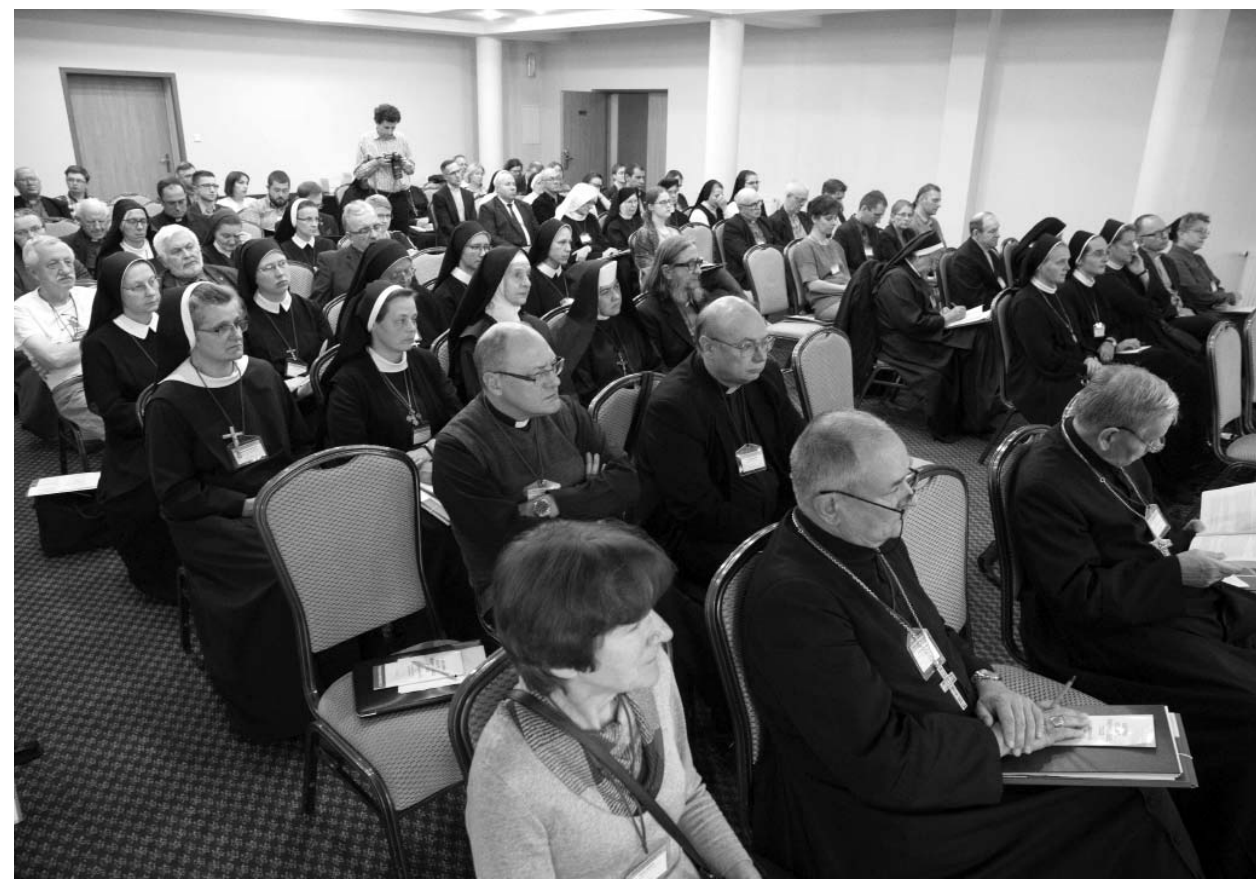

Fot. 5. Uczestnicy konferencji Archiwa kościelne w niepodległej Polsce. Fot. ks. Paweł Kłys.

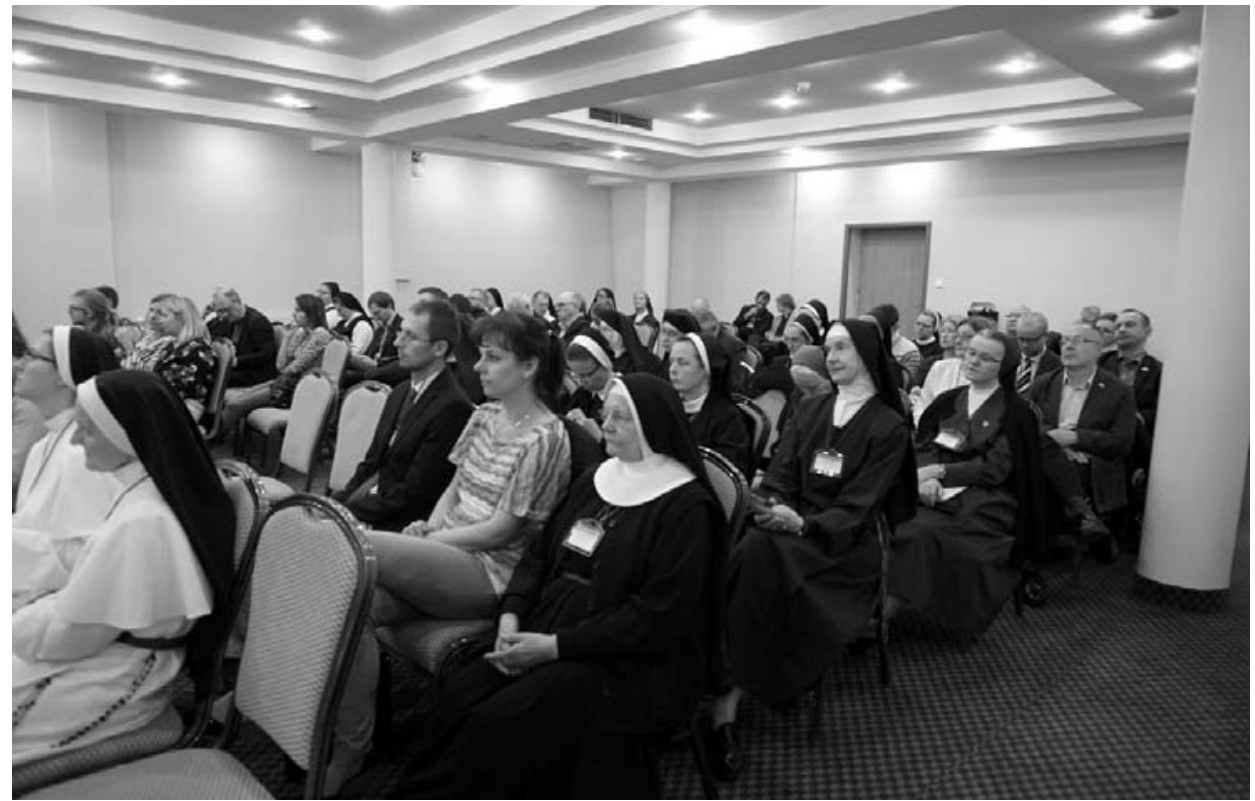

Fot. 6. Uczestnicy konferencji Archiwa kościelne w niepodległej Polsce. Fot. s. Natanaela Błażejczyk CSSF. 


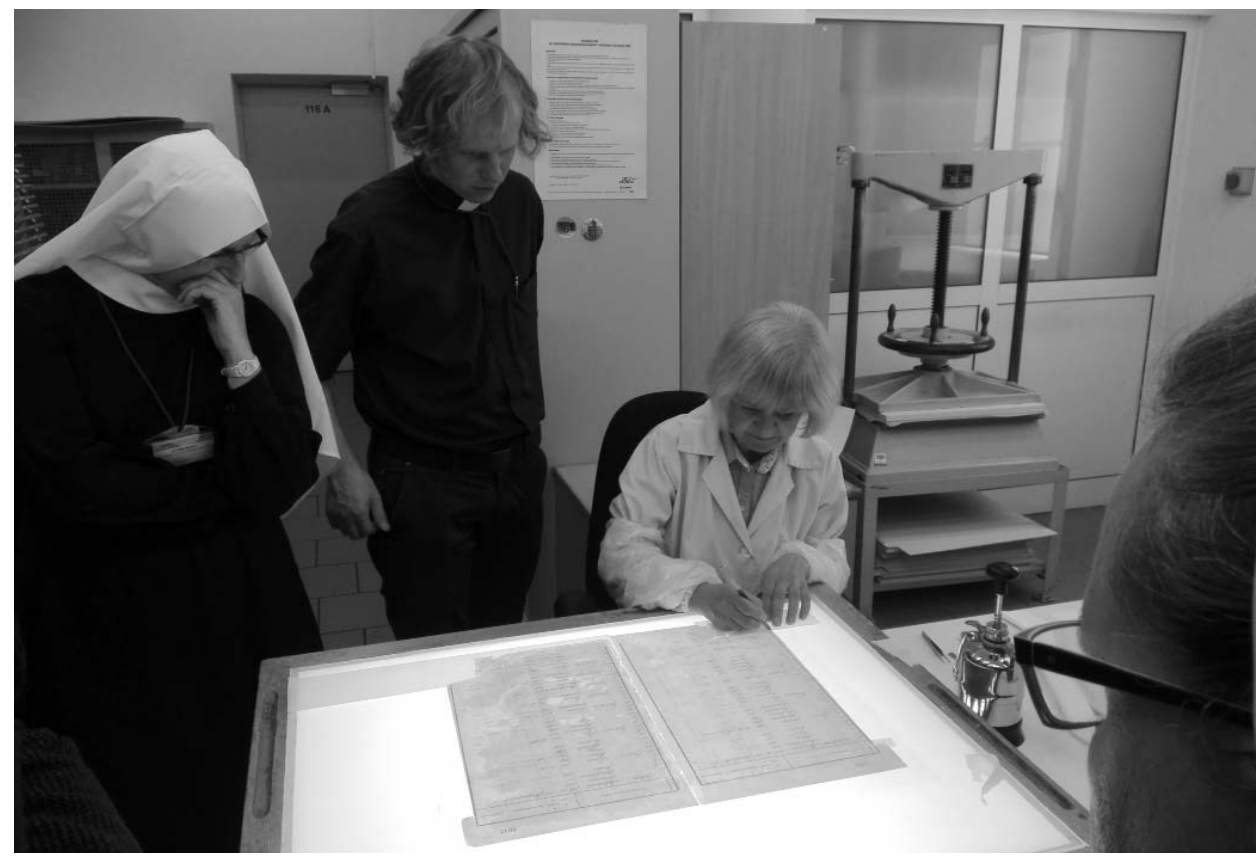

Fot. 7. Uczestnicy konferencji w pracowni konserwacji Archiwum Państwowego w Łodzi. Fot. s. Bernadeta Żabierek ZSNM.

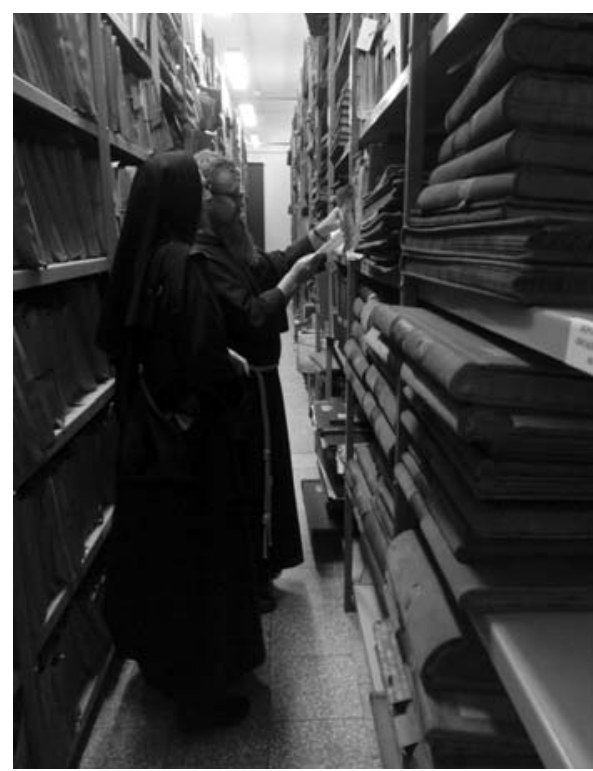

Fot. 8. Uczestnicy konferencji w magazynach Archiwum Państwowego w Łodzi. Fot. s. Maria Sylwia Bekus CR. 